\title{
THE IMPACT OF RELEVANT FACTORS ON WHEAT SUPPLY AND DEMAND IN THE REPUBLIC OF SERBIA
}

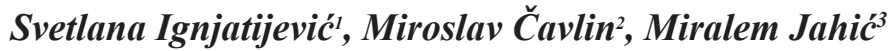

\begin{abstract}
Summary
The aim of the study is to conduct the wheat balances analysis, to research the supply and demand in the domestic market, and to examine the partial impact of the relevant factors on the supply and demand. The the research results of wheat production and trade flows can contribute to the increase of supply and to the structural changes in production, the strengthening of competitiveness, the increase of trade exchange, improvement in production and processing, new investments, higher employment rate, and so on. The methods used in the research are the wheat balances analysis, the functional and correlation analysis (the functional correlation analysis), the variance analysis, T-test, as well as other general methods. The results of the wheat production and consumption balances analysis indicate the existence of surplus and potential for export of an average of 805.29 thousand tons with a trend of increase after 2013. The impact of production, initial stocks, imports, and purchase prices on wheat supply is high $(R=0.99)$. The impact of consumption, sales prices, income, exports, and final stocks on wheat demand is high $(R=0.95)$. By analyzing the correlation coefficient of wheat production and supply, a coefficient of 0.96 was obtained, while for the wheat consumption and demand the obtained coefficient was 0.82, which indicates high correlation dependence. In the period 2000-2016, the export of wheat was increased 8.7 times along with the increase in price per $\mathrm{kg}$ and the total export value.
\end{abstract}

Key words: supply, demand, export, wheat, wheat balances analysis, correlation dependence.

JEL: C21, L11, Q13.

1 Svetlana Ignjatijević, Ph.D., Associate Professor, University Business Academy in Novi Sad, Faculty of Economics and Engineering Management in Novi Sad, Cvecarska Street no. 2, 21 000 Novi Sad, Serbia, Phone: +381 21400 484, E-mail: ceca@fimek.edu.rs

2 Miroslav Čavlin, Ph.D., Associate Professor, University Business Academy in Novi Sad, Faculty of Economics and Engineering Management in Novi Sad, Cvecarska Street no. 2, 21 000 Novi Sad, Serbia, Phone: +381 21400 484, E-mail: cmiros@gmail.com

3 Miralem Jahić, Ph.D., BH Telecom dd, Sarajevo, Bosnia and Herzegovina, Phone: +387 62981 000, e-mail: miralem.jahic.59@gmail.com

EP 2018 (65) 1 (143-156) 


\section{Introduction}

The agricultural policy of the Republic of Serbia gives special importance to wheat, primarily for the purpose of the nutrition of the population or food self-sufficiency, increasing the use of wheat as industrial raw material, and as an export potential.

Wheat production is primarily oriented towards meeting the needs of the domestic market. The quantities of wheat above the food self-sufficiency levels are characterised by high oscillations, so despite satisfactory quality, the manufacturers cannot count on stable export flows and revenues. To succeed in the market, especially the international market, the producers must introduce standards, innovate the production technology, and traders must be willing to adopt the marketing orientation (Puskaric et al., 2009).

Production and trade dynamics are impacted by agricultural policy measures, as well as marketing, which is becoming an increasingly powerful factor in the market. Agricultural policy measures were aimed at stabilizing the market, so production and sale prices, protective prices, and purchase prices were established to eliminate imports and stimulate domestic production and purchase. The Government establishes protective prices for wheat based on production costs, expected yield levels, as well as the domestic supply and demand ratio. To stabilize wheat production and trade flows, it is necessary for the Government to determine the minimum price in advance, i.e. before sowing, because in that case the producers would know the level of profit they can count with (Markovic et al., 2013). The study Mutavdžić et al. (2017) determined significant seasonal price fluctuations and concluded that the characteristics of price fluctuations indicate economically optimal time for selling and purchasing wheat (the optimal time for realization of wheat is the period from February to May).

The average per capita consumption of wheat in the Republic of Serbia is about 150 $\mathrm{kg}$, which is at the level of average global consumption. In the upcoming period, if the income of the population would not grow significantly, wheat consumption could be expected to grow in order to meet the necessary daily energy needs, because it is a relatively cheap source of energy (Markovic et al., 2013).

Producers or marketers have the task of exploring the needs and demands of consumers and by satisfying them, to ensure generation of profit. Consumers, on the other hand, satisfy their needs according to their preferences. When shopping, consumers choose between different products or different features of the same product, so is important to define which factors determine the demand. Based on defined demand, producers develop a product which would dominate the market and meet demand to the maximum extent. In doing so, they define the product quality, price, distribution, packaging, etc.

Market characteristics represent the most important factor regarding the profit level. "Various factors which have impact on the market position of business entities can be related to both the supply segment and the demand segment, and sometimes to both market processes". Samuelson gives great importance to the differentiation of products and to the influence of the seller or buyer on the process of price formation, 
showing in this way the importance of the number of participants in the market process" (Djordjevic, 2006, pp. 175, 176).

Unlike the markets of agricultural and food products in developed countries, which are well organized, in the Republic of Serbia, the market is disorganized, the competition undeveloped, and the economic relations between agricultural production and processing are disordered. The market in the Republic of Serbia has the characteristics of a perfectly competitive market regarding supply, and the characteristics of the oligopoly regarding demand. The purchase of agricultural products is disorganized, and vertical integration of producers and processors is absent. For all of these reasons, it is important to use the potentials and tools of the environment analysis, which is an important factor of business success, the purpose of which is to identify current and timely anticipate possible future situations in the environment (Cavlin, 2015).

The role of the government in modern market conditions is gaining importance, i.e., the government should encourage the establishing of modern purchasing and distribution centres in order to unify the supply of agricultural and food products. Economic integration and organization would increase production and processing, as well as the procurement of modern technology, investments, employment and product quality. In a word, the government should create a favourable environment for business organization, cluster organization, or other forms of business integration.

Supply and demand factors are different and show their impact in a different way. Dinu (2016) concluded that an efficient agri-food supply chain calls for the involvement of all participants: suppliers of raw materials and packaging, transporters, warehouses, clients. According to the findings of Haile et al. (2017) weather extremes - in terms of shocks in both temperature and precipitation - during crop growing months have detrimental impacts on the production an supply of the wheat. To cope with daunting challenge Tadesse (2017) have identified as the primary goals for sustainability $i$ the deployment of novel cultivars which include genetic resistances yield stability and increased yield potential, training and deployment of novel agronomical practices.

Although wheat production is an agricultural activity, in the analysis it is important to determine its effects on the society. Thus, at the macro level, the production of wheat, and at the micro level, the income it provides to producers, are determined.

Based on the available statistical data, the trends of production, i.e. supply and consumption of wheat in the Republic of Serbia in the period from 2000 to 2016, have been analyzed in this study. Supply and demand factors are different and show their impact in a different way. Supply and demand are confronted, conditioned by each other and harmonized. Wheat trade flows are impacted by prices and revenues, while non-priced factors are gaining in importance.

The consumption of wheat and various wheat products has specific characteristics (Smith, 2017). The traditional demand models start from the view point that consumers maximize their interest by choosing between several different products. Such models 
do not offer an answer to the question of why a consumer chooses a brand of product or products of specific producers (Trivic and Sagi, 2008). The characteristic of wheat demand is low flexibility, which means that with the change in prices and income the wheat demand shows relatively small changes. In analysing demand, the factors of demand, the aggregate demand, demand structure, demand trends, demand actors, noneconomic and other demand factors need to be studied.

This study specially deals with the available production potentials, wheat balances, factors that produce impact on the production, as well as the factors that have an impact on wheat supply and demand.

\section{The goal and importance of the study}

The goal of this study is to carry out the wheat balances analysis, to study the supply and demand in the domestic market, and to examine the partial impact of the relevant factors on the supply and demand.

The significance of the research is in the practical application of the obtained results. The assessment of the relation between the factors that determine the supply and demand will serve to assess the future movement of supply and demand, i.e. for the planning of sales both on domestic and foreign target markets. Similarly, the research results can be used by macroeconomic policymakers to regulate market flows, to prevent major disturbances, to ensure sufficiency, and to dynamize wheat exports as a strategic product.

\section{Methods of research and data sources}

The study has analyzed the production and consumption of wheat in the Republic of Serbia in the period 2000-2016 by method of wheat balances analysis. The wheat balances analysis was performed on the basis of the dynamic series analysis by threeyear periods, the functional, and the correlation analysis. The impact of domestic consumption, imports and purchase prices on wheat supply have been considered. At the same time, factors such as domestic consumption, exports, sales prices and GDP per capita have been studied, and their individual and partial impact on demand has been measured.

By multiple linear correlation analysis the impact of relevant factors on wheat supply and demand has been examined. The multiple linear equation reads (Kis, 2005):

$$
\mathrm{Y}=\mathrm{a}+\mathrm{b}_{1} \mathrm{x}_{1}+\mathrm{b}_{2} \mathrm{x}_{2}+\mathrm{b}_{3} \mathrm{x}_{3}+\ldots . .+\mathrm{b}_{\mathrm{n}} \mathrm{x}_{\mathrm{n}}, \mathrm{R}, \mathrm{S}_{\mathrm{y}}, \mathrm{r}_{1}, \mathrm{r}_{2} \ldots . \mathrm{r}_{\mathrm{n}} \text {, }
$$

By the analysis of variance (ANOVA) the probability of correlation has been determined. By the T-test the significance of each coefficient in predicting a certain phenomenon has been analyzed and the value of the partial correlation has been determined.

Available data of The Statistical Office of the Republic of Serbia, the Statistical Yearbook of Serbia, Agricultural statistics, Statistics of national accounts, as well as scientific and professional literature have been used in this study. 


\section{RESEARCH RESULTS AND DISCUSSION}

\section{Production and consumption of wheat in the Republic of Serbia}

At the European level, Serbia represents a significant producer of cereals and also the biggest regional producer, regarding the sown areas under wheat is on the twelfth place in Europe (Arsić et al., 2015). According to the findings of Munćan (2016) in the structure of field crop production in Vojvodina, the most common are two groups of crops: the grains/cereals, with dominant wheat and maize (Savić et al., 2016). In the period 2000-2016, in the Republic of Serbia, an average area of 579.64 thousand ha was used for wheat production. The average yield was $3.71 \mathrm{t} / \mathrm{ha}$, and production was $2,163.41$ thousand tons. In the observed period, the decrease in areas under wheat was recorded, but due to the increase in yield per ha, a minimal increase in production was achieved (Table 1).

Table 1. Production, areas under wheat and wheat yields

\begin{tabular}{|c|c|c|c|}
\hline Year & Area (000 ha) & $\begin{array}{c}\text { Yield } \\
(\mathbf{t} / \mathbf{h a})\end{array}$ & $\begin{array}{c}\text { Production } \\
\text { (000 t) }\end{array}$ \\
\hline$\varnothing 2000-2002$ & 678,80 & 3,23 & $2.231,00$ \\
\hline$\varnothing 2003-2005$ & 603,72 & 3,33 & $2.043,33$ \\
\hline$\varnothing 2006-2008$ & 528,82 & 3,70 & $1.944,33$ \\
\hline$\varnothing 2009-2011$ & 513,55 & 3,70 & $1.937,00$ \\
\hline$\varnothing 2012-2014$ & 564,93 & 4,07 & $2.332,67$ \\
\hline 2015 & 589,22 & 4,10 & $2.428,00$ \\
\hline 2016 & 595,12 & 4,80 & $2.885,00$ \\
\hline$\varnothing \mathbf{2 0 0 0 - 2 0 1 6}$ & $\mathbf{5 7 9 , 2 6}$ & $\mathbf{3 , 6 8}$ & $\mathbf{2 . 1 4 8 , 4 7}$ \\
\hline
\end{tabular}

Source: The Statistical Office of the Republic of Serbia, FAOSTAT

In the observed period, there is a fluctuation of sown areas, yields and total production. Inadequate measures of agricultural policy, as well as inadequate application of agrotechnical measures have proved as a limiting factor in increasing production volumes, which shows a negative effect on both the available quantities of wheat for the needs of the domestic market and on the exports.

Total available quantities of wheat in the observed period in the amount of 2,632.15 thousand tons/year, consist predominantly of the production - 2,346.71 thousand tons or $89.16 \%$ and transitional stocks -275.04 thousand tons or $10.45 \%$ (Table 2).

Total wheat consumption in the domestic market in the observed period amounts to an average of 1,826.85 thousand tons/year, of which 1,561.08 thousand tons or $85.45 \%$ represents domestic consumption, and 265.77 thousand tons or $14.55 \%$ are transitional stocks. The balance between total available quantities and total consumption with transitional stocks represents the available quantities for export in the amount of an average of 805.29 thousand tons (Table 2). 
The dynamic analysis, which has been used here, makes it possible, based on the data regarding production and consumption, as well as quality and prices, to anticipate the possibility of wheat exports in order to further stimulate production. In this way, the producers would be able to define the wheat sowing schedule and the volume of production in accordance with demand in the international market. The government would therefore have an interest to increase the competitiveness of producers in terms of quality, quantity and price by introducing incentive economic measures.

Table 2. Balance of wheat production and consumption in the Republic of Serbia (in 000 tons)

\begin{tabular}{|c|c|c|c|c|c|c|c|c|}
\hline Category & $\mathbf{2 0 0 0 .}$ & Ø01-03 & Ø04-06 & Ø07-09 & Ø10-12 & Ø13-15 & $\mathbf{2 0 1 6}$ & Ø00-16 \\
\hline Initial stocks & 300,0 & 331,3 & 334,3 & 404,7 & 307,33 & 111,67 & 218 & 275,04 \\
\hline $\begin{array}{c}\text { Domestic } \\
\text { production }\end{array}$ & $1.924,0$ & $2.044,7$ & $2.213,3$ & $2.009,0$ & $1.888,33$ & $2.501,67$ & 2.885 & $2.346,71$ \\
\hline $\begin{array}{c}\text { Total } \\
\text { available } \\
\text { quantities }\end{array}$ & $\mathbf{2 . 2 2 4 , 0}$ & $\mathbf{2 . 3 7 6 , 0}$ & $\mathbf{2 . 5 4 7 , 7}$ & $\mathbf{2 . 4 1 3 , 7}$ & $\mathbf{2 . 2 0 9 , 0 0}$ & $\mathbf{2 . 6 3 2 , 6 7}$ & $\mathbf{3 . 1 2 3}$ & $\mathbf{2 . 6 3 2 , 1 5}$ \\
\hline $\begin{array}{c}\text { Total domestic } \\
\text { consumption }\end{array}$ & $1.921,0$ & $1.912,3$ & $1.913,3$ & $1.622,3$ & $1.429,67$ & $1.298,00$ & 1.376 & $1.561,08$ \\
\hline Final stocks & 200,0 & 297,7 & 438,0 & 418,7 & 110,67 & 205,33 & 195 & 265,77 \\
\hline $\begin{array}{c}\text { Total } \\
\text { consumption }\end{array}$ & $\mathbf{2 . 1 2 1 , 0}$ & $\mathbf{2 . 2 1 0 , 0}$ & $\mathbf{2 . 3 5 1 , 3}$ & $\mathbf{2 . 0 4 1 , 0}$ & $\mathbf{1 . 5 4 0 , 3 3}$ & $\mathbf{1 . 5 0 3 , 3 3}$ & $\mathbf{1 . 5 7 1}$ & $\mathbf{1 . 8 2 6 , 8 5}$ \\
\hline $\begin{array}{c}\text { Surplus } \\
\text { Surplo }\end{array}$ & $\mathbf{1 0 3 , 0}$ & $\mathbf{1 6 6 , 0}$ & $\mathbf{1 9 6 , 3}$ & $\mathbf{3 7 2 , 7}$ & $\mathbf{6 6 8 , 6 7}$ & $\mathbf{1 . 1 2 9 , 3 3}$ & $\mathbf{1 . 5 5 2}$ & $\mathbf{8 0 5 , 2 9}$ \\
\hline
\end{tabular}

Source: The Statistical Office of the Republic of Serbia, FAOSTAT (calculated by the author)

The wheat balances analysis shows that the total available quantities of wheat in 2016 are higher than in 2000 by $40.4 \%$. Total consumption in 2016 decreased in relation to 2000 , but also in relation to the average consumption in the analyzed period.

Total available quantities of wheat, with certain oscillations, are constant observing three-year periods, which is also the case with the movement of available consumption. The balance surplus of wheat, of the average 805.29 thousand tons, shows an increasing trend in the analyzed period, especially after 2013.

The conducted wheat production and consumption balances analysis shows the existence of available quantities for export. However, from an economic point of view, it would be more profitable to process the wheat into a range of final products (Djuric et al., 2017) and export it in this form to the international market. By wheat processing, the value of the basic raw material, the degree of utilization of processing capacities, and the employment are increased, a rich range of products is created and produced in accordance with demand and consequently, and a greater value is achieved, which has a positive impact on the production and processing economy. 


\section{Factors that have impact on wheat supply and demand}

In our conditions, the production and supply of wheat is relatively unstable due to the high degree of dependence on natural, economic, material and technical and agroeconomic factors. The wheat demand shows, as a rule, low flexibility, because wheat products are relatively cheap and have good substitutes (Pejanovic, 2007, p. 213). Due to the low flexibility of consumption, wheat demand is a relatively stable market category.

Delivery of wheat to the market is performed through an organized transport network, i.e., by indirect transport, while an insignificant part is placed on the market directly. Wheat is one of the most actively traded agricultural commodities on stock exchange. Trade in rural markets amounts to only $0.3 \%$ of the annual production (Djorovic and Tomin, 2010; Markovic et al., 2013).

As for the wheat trade, it has recently been going on through the agricultural product trade exchange also in the form of "unripe wheat" trade, i.e., the sales contracts are concluded already in March and April and wheat is delivered immediately after the harvest (Markovic et al., 2013).

The wheat supply is adversely affected by (Vlahovic, 2003):

- Adverse conditions of operation in the agro-industrial complex;

- Low purchase (protected) price, which often barely covers production costs;

- Insufficient incentive measures to dynamize production, and consequently the wheat supply;

- Unregulated relations between producers, mill and bakery and other industries using wheat flour as the basic raw material.

The factors having impact on the wheat supply and demand have been analyzed. The analysis has measured the impact of production, initial stocks, imports and purchase prices on wheat supply, as well as the impact of consumption, sales prices, final stocks, income and exports on wheat demand.

By regression/correlation analysis, multiple $(\mathrm{R})$ and partial $(\mathrm{r})$ impact of domestic production $\mathrm{X}_{1}$, initial stocks $\mathrm{X}_{2}$, imports $\mathrm{X}_{3}$ and purchase prices $\mathrm{X}_{4}$ on wheat supply $\mathrm{Y}$ have been analysed. By regression/correlation analysis, multiple $(\mathrm{R})$ and partial $(\mathrm{r})$ impact of domestic consumption $\mathrm{X}_{1}$, sales prices $\mathrm{X}_{2}$, income $\mathrm{X}_{3}$, exports $\mathrm{X}_{4}$ and final stocks $\mathrm{X}_{5}$ on wheat demand $\mathrm{U}$ have been analysed. 
Table 3. The impact of factors on wheat supply and demand

\begin{tabular}{|l|l|l|l|l|l|l|}
\hline & & Production & $\begin{array}{l}\text { I n i t i a I } \\
\text { stocks }\end{array}$ & Imports & $\begin{array}{l}\text { Purchase } \\
\text { prices }\end{array}$ & \\
\hline Supply function & R & r1 & r2 & r3 & r4 & \\
\hline $\begin{array}{l}\mathrm{Y}=835,85+0,77 \mathrm{H}_{1}+0,53 \mathrm{H}_{2}-2,07 \mathrm{H}_{3} \\
+\end{array}$ & 0,993 & 0,955 & 0,339 & 0,150 & $-0,247$ & \\
\hline Demand function & & $\begin{array}{l}\text { D o m e s t i c } \\
\text { consumption }\end{array}$ & $\begin{array}{l}\text { S a I e s } \\
\text { prices }\end{array}$ & Income & Exports & $\begin{array}{l}\text { F i n a I } \\
\text { stocks }\end{array}$ \\
\hline $\begin{array}{l}\mathrm{U}=-216,89+1,095 \mathrm{H}_{1}+0,01 \mathrm{H}_{2}+ \\
1,223 \mathrm{H}_{3}+0,097 \mathrm{H}_{4}-0,34 \mathrm{H}_{5}\end{array}$ & 0,946 & 0,821 & 0,0117 & 0,00139 & 0,239 & $-0,134$ \\
\hline
\end{tabular}

Source: The Statistical Office of the Republic of Serbia (calculated by the author)

The coefficient of determination regarding wheat shows that $92 \%$ of the total wheat supply change is explained by the impact of the analyzed factors. The analysis of variance (ANOVA) has determined the probability of the existence of correlation. The empirical level of $\mathrm{F}$ distribution (70.105) is greater than the critical value of $\mathrm{F}$ (significance F) distribution, which indicates that the high value of $\mathrm{F}$ is not random and that the regression equation is relevant for predicting wheat supply. By the T-test, the significance of each coefficient in predicting wheat supply has been analyzed. The absolute values of $\mathrm{t}$ production statistics and the initial stocks are higher in relation to the critical value $t$ ( 4 degrees of freedom and $\alpha=0.05 ; 2.7764$ ) and are important for predicting the total supply. Concerning the wheat supply, there is a positive and negative agreement in variations. The impact of domestic production has a positive impact on supply. On condition that there is no change in other factors, the increase in domestic production per measuring unit will lead to an increase in the supply by 0.77 thousand tons. Concerning initial stocks, there is a positive relation between the analyzed factors. Increase in the initial stocks will result in the increase of the wheat supply by 0.53 thousand tons. Wheat import is insignificant and any change in imports has a negative impact on the supply. The change in purchase prices has a negative impact on the wheat supply.

By the correlation analysis of domestic production and total wheat supply, a coefficient of 0.96 has been obtained, which shows high correlation dependence. The coefficient of partial correlation between the initial stocks and imports shows a medium and minimal correlation with wheat supply. The analysis of purchase prices shows negative correlation dependence between the examined factors.

The coefficient of determination shows that $89.47 \%$ of the change in the total wheat demand is explained by the impact of domestic consumption, sales price, income, exports and final stocks. The change in domestic consumption by measuring unit corresponds to an increase in the total demand by 1.095 thousand tons. Analysis of the variance (ANOVA) determined the probability of the existence of correlation. The empirical level of F distribution (5.099) is lower than the critical value of the F (significance F) 
distribution, which shows that the regression equation is not relevant for predicting the total wheat demand. By the T-test, the significance of each coefficient in predicting the total wheat demand has been analyzed. The absolute values of $t$ statistics of domestic consumption are greater than the critical value $\mathrm{t}$ ( 3 degrees of freedom and $\alpha=0.05$; 3.182) and are important for predicting the total demand. Concerning the wheat demand, there is a positive and negative correlation of factors. The change in domestic consumption by measuring unit corresponds to an increase in the total demand by 1.095 thousand tons. The change in exports by measuring unit corresponds to an increase of about 0.097 thousand tons of total wheat demand. Change in final stocks has a negative impact on wheat demand.

By the correlation analysis of wheat consumption and demand, a coefficient of 0.821 has been obtained, which indicates high correlation dependence. The coefficient of sales prices, income, final stocks and demand indicates that there is minimal and negative correlation dependence between the observed factors. Correlation coefficient between exports and total wheat demand indicates minimal correlation dependence.

\section{Impact of factors on wheat exports}

Changes in the international wheat market have been extremely dynamic showing trends of production increase, achieving self-sufficiency in most countries and growing supply in the international market (Pejanovic et al., 2006).

Domestic market limitations cannot provide economies of scale, so export is one of the most important instruments for strengthening the competitive position of the domestic company in the international market (Djuric et al., 2017).

Some countries, i.e., economic groups, are closed, using different types of barriers when importing wheat. Such barriers are reflected in imposing standard customs restrictions, while various quantitative restrictions are much more used, which represents a new form of measures in agricultural protectionism, quality standards, sanitary regulations, etc. (Markovic et al., 2013).

In the period 2000-2016, the export of wheat increased 8.7 times with the increase in price per $\mathrm{kg}$ and in total export value.

Table 4. Export of wheat from the Republic of Serbia

\begin{tabular}{|l|l|l|l|}
\hline Years & Quantity (t) & $\mathbf{\$ / k g}$ & Value (\$) \\
\hline 2000 & $103.047,80$ & 0,12 & $12.345,29$ \\
\hline$\varnothing 01-03$ & $230.838,64$ & 0,12 & $19.314,92$ \\
\hline$\varnothing 04-06$ & $121.772,97$ & 0,14 & $16.445,45$ \\
\hline$\varnothing 07-09$ & $215.095,27$ & 0,23 & $46.385,48$ \\
\hline$\varnothing 10-12$ & $355.806,17$ & 0,27 & $93.984,20$ \\
\hline
\end{tabular}




\begin{tabular}{|l|l|l|l|}
\hline Years & Quantity (t) & $\mathbf{\$ / k g}$ & Value (\$) \\
\hline$\varnothing 13-15$ & $650.637,83$ & 0,22 & $148.440,97$ \\
\hline $\mathbf{2 0 1 6}$ & $892.362,00$ & 0,16 & $143.432,80$ \\
\hline
\end{tabular}

Source: The Statistical Office of the Republic of Serbia and UN Comtrade (calculated by the author)

The price is a significant factor regarding wheat demand on both domestic and foreign markets. On the one hand, the price is a demand factor, and on the other hand the price is impacted by a number of factors: production costs, productivity, consumption preferences, competition, and economic policy. In the previous period, there was an increase in wheat prices in the world, due to increased demand, reduced stocks in recent years, problems in production caused by climate change and reduction of available cultivable land in the world. The levels of domestic wheat prices depend on the movement of prices in the international market, i.e. relationship between supply and demand. The wheat export price analysis shows a significant fluctuation by three-year periods.

Table 5 shows the export of the first 15 wheat products according to the value of exports. The export is dominated by common wheat, sweet biscuits and flour, actually by the products of the lowest level of processing, which is not favourable. As earlier research by Raičević et al. (2012) shows wheat flour and other grain mill products have a high value of export and there was a significant increase of export and obtained exporting price.

Table 5. Export of wheat products in 2016

\begin{tabular}{|c|c|c|c|c|}
\hline $\begin{array}{l}\text { Item } \\
\text { No. }\end{array}$ & Products & 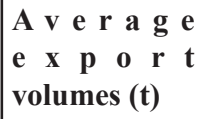 & $\begin{array}{l}\text { A v e r a g e } \\
\text { export value } \\
(000 \text { USD) }\end{array}$ & $\begin{array}{l}\text { P r i c e } \\
\text { USD/kg }\end{array}$ \\
\hline 1. & Common wheat, other & $298.311,52$ & $61.840,09$ & 0,21 \\
\hline 2. & Sweet biscuits, wafer biscuits and sheets & $19.777,12$ & $54.619,38$ & 2,76 \\
\hline 3. & Wheat flour & $128.455,03$ & $40.328,34$ & 0,31 \\
\hline 4. & Other bakery products & $9.496,08$ & $22.457,89$ & 2,36 \\
\hline 5. & $\begin{array}{l}\text { Products obtained by swelling and roasting of } \\
\text { cereals }\end{array}$ & $3.074,56$ & $9.964,65$ & 3,24 \\
\hline 6. & Hard wheat, other & $44.289,05$ & $9.798,53$ & 0,22 \\
\hline 7. & Grits and corn flour & $28.793,78$ & $9.167,66$ & 0,32 \\
\hline 8. & Common wheat, for sowing & $15.275,70$ & $3.871,42$ & 0,25 \\
\hline 9. & Pasta, uncooked, unstuffed, other & $3.608,38$ & $2.752,42$ & 0,76 \\
\hline 10. & Malt, fried or not (including starch flour) & $5.347,59$ & $2.330,29$ & 0,44 \\
\hline 11. & Wheat flour & $6.390,20$ & $1.791,28$ & 0,28 \\
\hline 12. & $\begin{array}{l}\text { Mixtures and dough for bakery products from } \\
048.4\end{array}$ & $1.491,27$ & $1.711,04$ & 1,15 \\
\hline
\end{tabular}




\begin{tabular}{|l|l|r|r|l|}
\hline 13. & Cereal sprouts, whole, rolled, flakes, milled & $2.946,64$ & $1.046,12$ & 0,36 \\
\hline 14. & Corn flour & $2.647,42$ & 979,23 & 0,37 \\
\hline 15. & Pasta, uncooked, unstuffed, with eggs & 949,05 & 753,47 & 0,79 \\
\hline
\end{tabular}

Source: The Statistical Office of the Republic of Serbia and UN Comtrade (calculated by the author)

Export of wheat from the Republic of Serbia, in the period 2000-2016, has the structural characteristics of exports of undeveloped countries. The export structure of the Republic of Serbia is significantly different from the average export structure of the economically developed countries. The inadequacy of the export structure is also reflected in a low similarity with the average import structure on export markets. Structural non-similarity between exports and imports, limits the possibility of the increase of exports and decrease of the foreign trade deficit.

Over the last few years, exports have relied on previously developed capacities, limited in volume and with backward technology. The prices of agricultural products of domestic exports are lower in relation to the effective prices of products of higher processing levels. Thus, exports of predominantly primary products/raw materials result in lower effects. The increase in exports was achieved in sectors that include products of a lower degree of finalization.

Although the export of agricultural and food products has a significant share in the export structure of the Republic of Serbia, its competitiveness is at a low level, and the increase in competitiveness and the degree of processing of agricultural and food products is considered key factors for dynamizing production and trade flows (Djuric et al., 2017).

In addition to stable and sustainable growth of production and product quality, the strategy for increasing the export of agricultural and food products also includes both adjusting the export structure to the requirements of import demand and improving competitiveness, primarily by using comparative advantages.

\section{Conclusion}

Unlike the market of agricultural and food products in developed countries, which operates successfully, in the Republic of Serbia, it is unorganized, the competition is underdeveloped, and the economic relations between agricultural production and processing are disordered. The market in the Republic of Serbia has the characteristics of a perfectly competitive market regarding supply, and the characteristics of the oligopoly regarding demand. The purchase of agricultural products is disorganized, i.e. there is no cooperation between the producers and processors.

The research concerning the wheat supply and demand should contribute to both the increase of supply and structural changes in production, as well as to the development of quality range of products in processing, along with permanent meeting of the demand. 
The slight increase in wheat production in the analyzed period is the result of an increase in the average yield. Due to inadequate measures of agricultural policy, undefined starting conditions for sowing and inadequate agricultural organization, there is a trend of decrease and fluctuation in wheat growing areas. The relatively lower yields in wheat production show that there are reserves for increasing productivity, and therefore also competitiveness in order to meet the domestic market, and dynamize exports. The wheat balances and the wheat balances analysis, showing a surplus of wheat, indicate that we can be a net exporter of this strategically important product.

The impact of production, initial stocks, imports and purchase prices on wheat supply is high $(\mathrm{R}=0.99)$. The impact of consumption, sales price, income, exports and final stocks on wheat demand is also high $(\mathrm{R}=0.95)$. The analysis of correlation coefficient of the domestic production and the total wheat supply has resulted in the coefficient of 0.96, and the analysis of correlation coefficient of the wheat consumption and demand, in the coefficient of 0.82 , which shows high correlation dependence.

In order to dynamize exports and generate higher profits, the wheat production should be focused on wheat processing into a diversified quality range of products in accordance with demand. By agricultural property aggregation, by increasing the number of commercial farms, by implementation of legal, economic and agrotechnical measures, it is possible to overcome the extensive wheat production and strengthen the competitiveness in the foreign markets. Additionally, it is necessary for producers to adjust the production structure and products, in terms of quality, quantity and prices, to the requirements of consumers or foreign customers in order to increase exports and generate higher profits.

\section{Literature}

1. Arsić, S., Kljajić, N., \& Jovanović, M. (2015). Korišćenje poljoprivrednog zemljišta kao osnovnog kapaciteta za proizvodnju kukuruza i pšenice u Srbiji i zemljama bivše Jugoslavije. Ekonomika, 61(2), 103-116.

2. Čavlin, M. (2015). Strateška analiza perfomansi preduzeća iz trgovine farmaceutskim proizvodima u Republici Srbiji primenom integrisanog sistema pokazatelja, Megaterend revija, 1, 237-256.

3. Dinu, D. M. (2016). Supply chain performance within agri-food sector. Ekonomika poljoprivrede, 63(3), 919-928.

4. Djuric, D., Ristic, J., Djuric, D., Vujanic, I. (2017). Export of Agricultural and Food Products in the Function of Economic Growth of Republic of Serbia, Economics of Agriculture, 64 (3); 887-900.

5. Đorđević, D. (2006). Mikroekonomija - savremeni pristup, Privredna akademija, Spoljnotrgovinski fakultet, Novi Sad.

6. Đorović, M., Tomin, A. (2010). Tržište i promet poljoprivrednih proizvoda, Poljoprivredni fakultet, Beograd. 
7. FAOSTAT (accessed: 28.10.2017) - www.faostat.fao.org

8. Haile, M. G., Wossen, T., Tesfaye, K., \& von Braun, J. (2017). Impact of climate change, weather extremes, and price risk on global food supply. Economics of Disasters and Climate Change, 1(1), 55-75.

9. Kiš, T. i sar. (2005). Kvantitativni metodi u ekonomiji, Subotica, Ekonomski fakultet.

10. Marković, J., Prodanović, R., Mutibarić, J. (2013). Proizvodnja i promet pšenice u Srbiji. Ekonomika, 59 (2), 92-100.

11. Munćan, M. (2016). Uticaj mineralne ishrane i atmosferskih padavina na prinos ratarskih useva porodičnih gazdinstava. Ekonomika poljoprivrede, 63(3), 817833.

12. Mutavdžić, B., Novković, N., Vukelić, N., \& Novaković, T. (2017). Mesečna kolebanja cena zrna u Srbiji. Journal on Processing and Energy in Agriculture, 21(3), 181-184.

13. Pejanović, R. (2007). Uvod u mikroekonomiju, Novi Sad, Poljoprivredni fakultet.

14. Pejanović, R., Cvijanović, D., Nikolić, M., Tica, N. (2006). Kretanja na tržištu pšenice i brašna u svetu i Srbiji i Crnoj Gori, Naučni institut za ratarstvo i povrtarstvo Novi Sad, "Zbornik radova”, Sveska 42.

15. Puškarić, A., Cvijanović, D., Arsenijević Ž. (2009). Izvoz kao faktor podsticanja proizvodnje ratarskih proizvoda, Zbornik naučnih radova, Institut za ekonomiku poljoprivrede, Beograd, Vol. 15, br. 1-2.

16. Raičević, V., Ignjatijević, S., \& Matijašević, J. (2012). Economic and legal determinants of export competitiveness of the food industry of Serbia. Industrija, 40(1), 201-226.

17. Republički zavod za statistiku Srbije (accessed: 28.10.2017) - www.stat.gov.rs

18. Savić, L., Bošković, G., \& Mićić, V. (2016). Agroindustrija Srbije - potencijali i perspektive. Ekonomika poljoprivrede, 63(1), 107-122.

19. Smith, S. (2017). Wheat. Agricultural Commodities, 7(3), 27.

20. Tadesse, W. (2017). Improving wheat production in the CWANA region. Burleigh Dodds Science Publishing Ltd.

21. UN Comtrade Database (accessed: 14.10.2017) - http://comtrade.un.org

22. Vlahović, B. (2003). Tržište poljoprivredno - prehrambenih proizvoda, specijalni deo - knjiga II, Poljoprivredni fakultet, Novi Sad. 


\title{
UTICAJ RELEVANTNIH FAKTORA NA PONUDU I TRAŽNJU PŠENICE U REPUBLICI SRBIJI
}

\author{
Svetlana Ignjatijević, Miroslav Čavlin ${ }^{5}$, Miralem Jahić ${ }^{6}$
}

\begin{abstract}
Sažetak
Cilj rada je da se izvrši bilansna analiza pšenice, istraži ponuda i tražnja na domaćem tržištu, te ispita parcijalni uticaj relevantnih faktora na ponudu i tražnju.

Rezultati istraživanja proizvodno-prometnih tokova pšenice mogu doprineti povećanju ponude i strukturnim promenama u proizvodnji, jačanju konkurencije, rastu razmene, unapređenju proizvodnje i prerade, novim investicijama, rastu zaposlenost $i d r$.

Od metoda u istraživanju se koristi bilansna analiza, funkcionalna $i$ korelaciona analiza, analiza varijanse, T-test, kao i drugi opšti metodi.

Rezultati bilansne analize proizvodnje i potrošnje pšenice ukazuju na postojanje suficita i potencijala za izvoz u iznosu od prosečno 805,29 hiljada t sa trendom povećanja nakon 2013. godine.

Uticaj proizvodnje, početnih zaliha, uvoza i otkupnih cena na ponudu pšenice je visok $(R=0,99)$. Uticaj potrošnje, prodajnih cena, dohotka, izvoza i krajnjih zaliha na tražnju pšenice je visok $(R=0,95)$. Analizom koeficijenta korelacije proizvodnje $i$ ponude pšenice dobijen je koeficijent 0,96, a potrošnje i tražnje pšenice dobijen je koeficijent 0,82, što ukazuje na visoku korelacionu zavisnost. U periodu 2000-2016. godine izvoz pšenice povećan je 8,7 puta uz povećanje cene po kg i ukupne vrednosti izvoza.
\end{abstract}

Ključne reči: ponuda, tražnja, izvoz, pšenica, bilansna analiza, korelaciona zavisnost.

4 Prof. dr Svetlana Ignjatijević, Vanredni profesor, Univerzitet Privredna akademija u Novom Sadu, Fakultet za ekonomiju i inženjerski menadžment u Novom Sadu, Cvećarska 2, 21000 Novi Sad, Srbija, Telefon: +381 21400 484, E-mail: ceca@fimek.edu.rs

5 Prof. dr Miroslav Čavlin, Vanredni profesor, Univerzitet Privredna akademija u Novom Sadu, Fakultet za ekonomiju i inženjerski menadžment u Novom Sadu, Cvećarska 2, 21000 Novi Sad, Srbija, Telefon: +381 21400 484, E-mail: cmiros@gmail.com

6 Dr Miralem Jahic, BH Telekom dd, Sarajevo, Bosna i Hercegovina, Telefon: +387 62981000 , e-mail: miralem.jahic.59@gmail.com 